\title{
О РАБОТЕ МЕЖДУНАРОДНОЙ КОНФЕРЕНЦИИ «ДРЕВНОСТИ ВОСТОЧНОЙ ЕВРОПЫ, ЦЕНТРАЛЬНОЙ АЗИИ И ЮЖНОЙ СИБИРИ В КОНТЕКСТЕ СВЯЗЕЙ И ВЗАИМОДЕЙСТВИЙ В ЕВРАЗИЙСКОМ КУЛЬТУРНОМ ПРОСТРАНСТВЕ (НОВЫЕ ДАННЫЕ И КОНЦЕПЦИИ)»
}

\author{
(C) 2020 г. Т. Н. Лошакова, Е. В. Дубягина
}

18-22 ноября 2019 года в г. Санкт-Петербург на базе Института истории материальной культуры РАН и Государственного Эрмитажа прошла международная конференция «Древности Восточной Европы, Центральной Азии и Южной Сибири в контексте связей и взаимодействий в евразийском культурном пространстве (новые данные и концепции)», посвященная 90-летию со дня рождения В. М. Массона и 80-летию со дня рождения В. С. Бочкарева. В работе конференции приняли участие ученые из 22 стран, было прочитано и обсуждено 232 доклада. Казахстан представляли исследователи из Института археологии им. А. Х. Маргулана, Сарыаркинского археологического института при Карагандинском государственном университете им. академика Е. А. Букетова, Костанайского государственного университета им. А. Байтурсынова, Павлодарского государственного университета им. С. Торайгырова, Международного казахско-турецкого университета имени Х. А. Ясави, Кызыл-Ординского госуниверситета им. Коркыта ата, Центра сближения культур под эгидой ЮНЕСКО (Алматы). Доклады участников были посвящены проблемам хронологии и культурогенеза древних обществ, искусству древнего населения, степным культурам эпохи энеолита-бронзы.

Ключевые слова: археология, Евразия, Центральная Азия, Ближний Восток, Европа, Кавказ, неолит, эпоха бронзы, ранний железный век, античность, средневековье, искусство, хронология, культурогенез, городская культура, скотоводы, земледельцы

Работу конференции организаторы разделили на две большие части. Первая - «Древняя Центральная Азия в контексте евразийского культурного пространства (новые данные и концепции)» - была посвящена 90-летию со дня рождения Вадима Михайловича Массона. Вторая часть конференции «Связи, контакты и взаимодействия древних культур Северной Евразии и цивилизаций Востока в эпоху палеометалла» была посвящена 80-летию со дня рождения Вадима Сергеевича Бочкарёва (см. материалы на сайте ИИМК РАН: http://www.archeo.ru/).

В ходе конференции были обсуждены доклады по следующим на- правлениям: 1. Проблемы хронологии и культурогенеза древних земледельческих обществ Центральной Азии, Ближнего и Среднего Востока и ЮгоВосточной Европы (неолит-ранний железный век); 2. Культура городов Центральной Азии, Ближнего и Среднего Востока в античности и раннем средневековье; 3. Искусство древнего населения Центральной Азии, Ближнего и Среднего Востока от неолита до раннего средневековья; 4. Скотоводы евразийских степей, их контакты с населением земледельческих оазисов в бронзовом и железном веках; 5. Вопросы хронологии и культурогенеза эпохи бронзы Северной Евра- 
Лошакова T.H., Дубягина E.B. О работе международной конференции «Древности Восточной Европы, Центральной Азии и Южной Сибири...

зии; 6. Культуры Северной Евразии и Древний Китай; 7. Степные культуры эпох энеолита - бронзы Восточной Европы и Кавказа; 8. Эпоха бронзы Волго-Уральского региона.

Открытие конференции прошло в здании Эрмитажного театра, где с приветственным словом к участникам обратились директор ИИМК РАН, д.и.н. В. А. Лапшин, начальник Национального управления по охране, изучению и реставрации памятников истории и культуры Туркменистана, к.и.н. М. А. Мамедов и ректор СГСПУ, д.и.н. О. Д. Мочалов. Участники конференции вспоминали моменты совместной работы с В. М. Массоном, а также тепло поздравили В. С. Бочкарёва с юбилеем.

Об основных вехах жизни и научной деятельности В. М. Массона воспоминаниями о совместной работе поделилась в своем докладе Л. Б. Кирчо. Доклад был проиллюстрирован большим количеством фотографий, на которых исследователь был запечатлён за работой, в кругу коллег и семьи.

Доклады, представленные в первой части конференции, охватили широкий спектр исследований. Сюда вошли исследования теоретической направленности по проблемам использования дефиниций «культура», «комплекс», «период», «слой», «стадия», «фаза», «цивилизация», «эпоха», «этап» в научных публикациях, изыскания, посвященные древностям Южного Туркменистана в свете современного эволюционизма и проблемам ранней урбанизации (3500-1500 гг. до н.э.) Южной Месопотамии, системе расселения и структуре домостроения в VII-III тыс. до н.э.

Серия докладов была посвящена исследованию на территории Туркменистана. Освещение получили проблемы, связанные с вопросами хронологии и архитектуры неолитических и раннеэнеолитических обществ по материалам поселения
Монджуклы-депе, древнеземледельческого центра Алтын-депе, организации очагов и использованию огня в жизни ранних земледельцев Южного Туркменистана. Представлены материалы Дашлы-депе - многослойного доисторического памятника на юге Туркменистана, памятников культуры типа Яз в Серахском оазисе, изложены новые подходы к реконструкции систем древних каналов в долине Мургаба в эпоху бронзы. Анализу местонахождения, сырью, разнообразию форм и обработки крупных каменных изделий Маргианы эпохи бронзы посвящены доклады исследователей из России и Туркменистана.

Материалы, представленные с поселения Гонур-депе, включали в себя итоги краниологиеских исследований, изучения печатей, были посвящены находке полихромной росписи, результатам рентгенофлюоресценого анализа металлических зеркал из археологического комплекса, культуре земледелия древнего оазиса. Исследование памятников эпохи бронзы Таджикистана представлены предварительными итогами изучения могильника Фархор, результатами технико-типологического анализа нуклеусов гиссарской культуры на основе материалов неолитической стоянки Гуликандоз.

В серии докладов были подняты проблемы исследования неолита Южного Кавказа, формирования нового социально-культурного пространства - ранней земледельческой культуры Карабаха на Южном Кавказе в эпоху неолита, изучения южнокавказской группы раннеземледельческой культуры Азербайджана по материалам памятника Аликемектепе, погребальных сооружений майкопской культуры в контексте связей Кавказа и Передней Азии в IV тыс. до н.э.

Ряд докладов посвящен изучению памятников зарубежной Азии. В них отразились итоги исследования керамики и артефактов эпохи энеоли- 
та с поселения Мергар (Пакистан), вопросы древней металлообработки в южном округе Кухдашт в Луристане, изучение плавильного шлака из Харрехсее в раннем железном веке и культурных связей Ирана с сопредельными странами на примере терракотовых антропоморфных статуэток Гиляна в раннем железном веке (I тыс. до н.э.), а также представлено современное понимание проблем изучения раннего железного века в Бактрии на основе материалов Кайритского оазиса.

Большой блок докладов содержал в себе результаты междисциплинарных исследований памятников Колхиды II тыс. до н.э. Представлена реконструкция хозяйственного уклада жителей энеолитического поселения Илгынлы-депе на основе применения лингвистическо-археологического анализа, итоги археозоологических исследований филактериона крепости Узундара.

В работе секции «Культура городов Центральной Азии, Ближнего и Среднего Востока в античности и раннем средневековье» представлены доклады о раннем распространения буддизма за пределы Индии, о македонской кавсии на индо-иранском пограничье, изложены основные этапы развития древнего города Пайкенд, расположенного на юго-западной границе Бухарского оазиса, представлены модели формирования культуры древних земледельцев на территории Южного Приаралья, освещены проблемы формирования и хронологии урбанизированной культуры Хорезмского оазиса. Представлены результаты исследования археологических комплексов поселения Хумбузтепа, изучения фортификации крепости Узундара, рассмотрены вопросы формирования погребального обряда христиан в Центральной Азии домонгольского времени и оседло-земледельческого населения Мавераннахра (VII - начало VIII в.), исследованы этапы развития иконографии и распростране- ние иранских божеств в Центральной Азии в аршакидский и сасанидский периоды.

Серия докладов посвящена изучению хозяйств древних обществ: сельского хозяйства, продуктов питания, сырья для текстиля и строительства в Сасанидском Мерве, керамического производства и влияния греческой керамики на керамическое производство в Бактрии в эллинистический период, рассмотрена история изучения и перспективы исследований древнебактрийских фляг.

Представлены новые данные по топографии раннесредневекового Пенджикента, архитектурному изучению объекта IV городища Ак-Бешим и цитадели древнего и средневекового Самарканда.

В секции «Искусство древнего населения Центральной Азии, Ближнего и Среднего Востока от неолита до раннего средневековья» представлены сообщения об изобразительных памятниках окуневской культуры, рассмотрен образ быка в искусстве эпохи бронзы Центральной Азии и хтонические изображения хищников на оленных камнях Монголии, поднята проблема датировки битреугольного стиля в наскальном искусстве Центральной Азии и исследования фрагментов росписей древнего Эребуни, освещены истоки возникновения тюркских средневековых неполнофигурных изваяний, доложены результаты изучения антропоморфных фаллических амулетов как свидетельство культурных контактов между номадами и оседлым населением IV-VII вв. н.э., рассмотрены современные проблемы методологии исследования памятников доисторического искусства.

Доклады секции «Скотоводы евразийских степей, их контакты с населением земледельческих оазисов в бронзовом и железном веках» посвящены проблемам формирования и развития евразийского номадизма, взаимодействию подвижных ското- 
Лошакова T.H., Дубягина E.B. О работе международной конференции «Древности Восточной Европы, Центральной Азии и Южной Сибири...

водов и земледельцев на юге Таджикистана, воинским погребениям сакского времени в Чон-Алае. Особо выделялись доклады, посвященные изучению ямной культуры скотоводов Волго-Уральских степей, шерстяных тканей бронзового века Южной Сибири и шелкового головного убора хуннуского времени из кургана № 51 памятника Яломан-II (Центральный Алтай).

Отдельно хочется выделить доклады казахстанских исследователей. В докладе А. Н. Подушкина и А. В. Донца были представлены новые материалы, полученные при исследовании эталонных памятников арысской культуры Южного Казахстана (городище Культобе и Ушбастобе, катакомбные могильники Культобе и Кылышжар). В совместном докладе А. Н. Подушкина с российским исследователем Б. А. Раевым изложены новые материалы по первичной выплавки железа на городище Ушбастобе. История изучения и вопросы хронологии Борижарского могильника отражены в совместном докладе А. А. Ержигитовой и исследователя из Санкт-Петербурга А. И. Торгоева. В коллективном докладе исследователей И. А. Аржанцевой (Россия), Х. Г. Харке (Германия) и А. Тажекеева (Казахстан) освещены основные результаты исследований по проекту «Nomad state formation and urbanization: The early medieval town of Dzhankent (Aral Sea region, Kazakhstan)».

Работа второй части конференции, посвященная 80-летию со дня рождения В. С. Бочкарёва, началась с выступления юбиляра, который выразил благодарность за поздравления, высказанные в его адрес, и активное участие коллег-археологов в работе конференции. В своем выступлении «Археология на перекрестке гуманитарного и естественнонаучного знания» юбиляр обобщил широкий спектр материалов и данных, полученных с применением естественно- научных методов, привел примеры полученных выводов, которые обогатили современную науку.

В работе секции «Вопросы хронологии и культурогенеза эпохи бронзы Северной Евразии» рассматривались вопросы, связанные с ролью культурных связей в становлении и развитии металлопроизводства ямной культуры на территории Приуралья, определением времени контактов оседлых и пастушеских племен на территории южного Туркменистана; приведены новые данные по радиоуглеродной хронологии эпохи бронзы Минусинской котловины, которые позволили выявить более точные временные рамки существования отдельных археологических культур.

Блок докладов посвящен изучению древних производств. Отдельными исследованиями представлены результаты изучения тиглей и сопел из погребений «кузнецов-литейщиков» раннего и среднего бронзового века Восточной Европы, результаты первых исследований состава и технологии обработки железа в III - первой половине I тыс. до н.э. на юге Восточной Европы, итоги изучения техникотехнологического анализа майкопского и лейлатепинского керамического материала, двух стержневидных псалиев из оленьего рога, обнаруженных при раскопках цитадели Трои VI.

Исследователями были представлены новые данные по изучению абашевской культуры Приуралья, жаботинской археологической культуры, по исследованию генезиса и распространения дисковидных псалиев Северной Евразии, по комплексу бронзовых изделий эпохи поздней бронзы с территории курганной группы Войцеховского могильника, культурнохронологическим индикаторам раннегальштатского горизонта городища Картал.

В секции «Культуры Северной Евразии и Древний Китай» представлены материалы и результаты иссле- 
дований на могильнике афанасьевской культуры Карасук III, по формированию комплекса металлических изделий культуры Сыба (Ганьсуский коридор, Китай), краниологии чемурчекской культуры Западной Монголии, освещены проблемы хронологии и датирования на основе керамических комплексов бронзового века Нижней Ангары, выделены особенности сейминско-турбинских наконечников копий Обь-Иртышья.

Вопросам изучения и эволюции конского снаряжения эпохи поздней бронзы в Древнем Китае, погребений с обрядом трупосожжения в Саянском каньоне Енисея, влияния южных связей на культурогенез населения эпохи поздней бронзы юга Западной Сибири, а также итогам и перспективам исследований тагарской культуры Мариинской лесостепи и специфике формирования начальных этапов палеометалла на юге Западной Сибири посвящена серия докладов российских исследователей.

В докладах изложены результаты по изучению производственнотехнологических взаимодействий культур эпохи ранней бронзы Западной Сибири в области металлообработки, предложены выводы, полученные на основе радиоуглеродного датирования курганов с предметами китайского импорта из могильника скифской эпохи Чинета-II, проанализированы особенности формирования андроновских поселений в Минусинской котловине на основе материалов памятника Ключи и проблемы, связанные с изучением данного вида объектов.

Вопросы изучения погребального костюма населения андроновской культуры Алтая, изображения «распростертых» птиц селенгинских писаниц с оградками и их китайские датирующие параллели и особенности формирования жертвенных комплексов в эпоху поздней бронзы на основе материалов могильника Тар- тас (Барабинская лесостепь) подробно проанализированы в выступлениях российских исследователей.

Предложенная в сообщении реконструкция природных условий и хозяйственной деятельности населения поселения эпохи бронзы Березовая Лука (Алтай), представленная на основе комплексного исследования, вызвала бурное обсуждение присутствующих.

Интерес исследователей вызвали доклады по планиграфии некрополей быстрянской культуры Алтая в скифо-сакское время и планиграфии раннескифского «царского» кургана Туннуг.

Локально-хронологическиеособенности зооархеологических комплексов погребений тагарской культуры освещены в докладе кемеровских исследователей.

В ходе работы секции «Степные культуры эпох энеолита-бронзы Восточной Европы и Кавказа» представлены материалы по изучению древних орудий деревообработки из Майкопского кургана (Ошад), подняты вопросы по проблеме изучения финала среднего-позднего бронзового века Таманского полуострова, представлены результаты археологического и естественнонаучного исследования клада эпохи поздней бронзы «Батарейка», приведена хронологическая атрибуция позднего горизонта городища Рудь-Мэтониум, рассмотрены биосоциальные факторы культурогенеза бронзового века.

Большой блок докладов включал в себя материалы по изучению предметов из металла и развитию металлургического производства, где были выделены две фазы развития в металлопроизводстве раннего этапа средней бронзы Предкавказья и юговостока Русской равнины, рассмотрены вопросы, связанные с изучением и интерпретацией кладов с изделиями прикубанского очага металлургии и металлообработки позднего бронзо- 
Лошакова T.H., Дубягина E.B. О работе международной конференции «Древности Восточной Европы, Центральной Азии и Южной Сибири...

вого века, представлены результаты исследований металлопроизводства на памятниках эпохи бронзы Казахстана и бронзы-раннего железа Центрального Кавказа. Отдельный доклад посвящен результатам трасологического исследования «серпов» из клада Сосновая Маза.

На основе технико-технологического анализа рассмотрены вопросы по изучению керамики с примесью ракушки в культуре ТрипольеКукутени, подробно изложены результаты изучения технологии изготовления керамики в раннем железном веке Северного Причерноморья (памятники Поднестровья), представлены кавказские традиции в керамике восточноманычской культуры.

Обширные, аналитические доклады представлены исследователями по вопросам изучения поселений ингульской культуры, проблемам позднего Триполья, культуры Бабино на Нижнем Дону, по новым материалам неолита-энеолита Таловое I на Донском Левобережье и хронологии позднего энеолита Пруто-Днестровского междуречья на основе серии новых дат $\mathrm{C}^{14}$, которые позволили очертить точные хронологические рамки памятников в общей периодизации.

Исследователями представлены новые материалы по изучению памятников эпохи бронзы: мавзолея 7-го Разменного кургана в Закубанье, поселения комплекса Ноуа-СабатиновкаКослоджень-Тараклия-Гайдабул (Молдова), бытованию и датированию трансверсальных наконечников стрел усатовской культуры. Несколько докладов посвящены вопросам изобразительного искусства, где представлены материалы по предметным соответствиям сюжета «охоты» энеолитической стелы из Керносовки и результаты исследования изображений на стенах погребальных сооружений раннекатакомбного времени.

Серия докладов была посвящена вопросам изучения состава населе- ния Центрального Предкавказья VIIIVII вв. до н.э. и обряда демембрации в катакомбных погребениях СевероВосточного Приазовья. Этапы развития животноводства ямной и катакомбной культур были представлены в докладе П. А. Косинцева.

В работе секции «Эпоха бронзы Волго-Уральского региона» рассматривались вопросы развития комплексных обществ в степях Восточной Европы по материалам погребального обряда ямной культуры Волго-Уралья, погребений на основе материалов памятников синташтинского и петровского типа, погребальных комплексов абашевской культуры в Оренбургском Предуралье.

Большой блок вопросов был посвящен рассмотрению взаимодействия различных культур. Особое внимание вызвали доклады об особенностях срубно-андроновского взаимодействия на территории Оренбургского Предуралья и Самарского Поволжья в позднем бронзовом веке. На заседании представлены новые материалы полевых исследований поселения Левобережное (Синташта II), материалы по изучению Сосново-Мазинского клада из Хвалынского музея, некоторые итоги по исследованию технологии изготовления керамики населением развитого этапа срубной культуры Волго-Уралья.

Особое внимание привлек доклад российских коллег по исследованию материалов степного Поволжья эпохи бронзы с применением изотопного анализа, в котором авторы изложили свою методику исследования, дали несколько рекомендаций по изъятию проб для проведения анализа.

В особую группу выделим выступления казахстанских коллег. Так, В. А. Новоженов выступил с докладом «Изобразительные памятники как индикатор коммуникаций населения Центральной Азии в эпоху палеометалла». В выступлении Э. Р. Усмановой прозвучали результаты анализа 
технологических особенностей изготовления и семантической составляющей андроновского головного убора по материалам могильника Лисаковский I. Казахстанские комплексы елунинского типа были представлены в докладе И. В. Мерца. Вопросам возникновения, развития и перспективам изучения металлопроизводства в Жезказган-Улытауском горно-металлургическом центре посвящен доклад А. С. Ермолаевой и Е. В. Дубягиной, подготовленный совместно с российскими исследователями С. В. Кузьминых и М. Н. Анкушевым. В докладе российского ученого Н. А. Боковенко и В. Хорват рассмотрены некоторые аспекты проникновения центральноазиатского населения в Европейскую Скифию. В совместном сообщении новосибирского исследователя О. А. Митько и У. У. Умиткалиева представлены материалы исследования памятников эпохи бронзы на некрополе Кырыкунгир. В докладе И. В. Шевниной, А. В. Логвина, подготовленном совместно с исследовательницей из США И. П. Па- нюшкиной, были представлены новые данные междисциплинарных исследований синташтинских памятников Тургайского прогиба (Каратомар, Халвай 3, 5). Вопросы социальной стратификации синташтинских погребений были подробно проанализированы в выступлении сотрудника филиала Института археологии им. А.Х. Маргулана в г. Нур-Султан - А. И. Хаванского.

В ходе работы конференции были также представлены материалы полевых исследований 2018-2019 гг.; на основе новых данных естественнонаучных исследований дана современная оценка уже известным материалам, что вызвало активные дискуссии. Организаторами конференции был задуман большой и сложный в реализации проект, но все удалось! Удалось объединить и сблизить исследователей разных стран, дать толчок к развитию новых направлений в изучении древней истории, заострить внимание на вопросах, связанных с методологией исследований.

\section{Сведения об авторах:}

Лошакова Татьяна Николаевна - старший научный сотрудник, Институт археологии им. А.Х. Маргулана (г. Алматы, Казахстан); loshakovat@mail.ru

Дубягина Екатерина Викторовна - научный сотрудник, Институт археологии им. А.Х. Маргулана (г. Алматы, Казахстан); nkatykat@gmail.com

\section{Еуразиялық мәдени кеңістігіндегі байланыстар мен өзара қарым қатынастар контекстіндегі шығыс Еуропа, Орталық Азия және Оңтүстік Сібірдің ежелгі тарихы» (жаңа мәліметтер мен тұжырымдамалар)» атты халықаралық конференцияның жұмысы туралы}

\section{Т. Н. Лошакова, Е. В. Дубягина}

2019 жылдың 18-22 қарашасында Санкт-Петербург қаласында РҒА Материалдық мәдениет тарихы нституты және Мемлекеттік Эрмитаждың ұйымдастыруымен «Еуразиялық мәдени кеңістіктігіндегі байланыстар мен өзара қарым-қатынастар контекстіндегі Шығыс Еуропа, Орталық Азия және Оңтүстік Сібірдің ежелгі тарихы» атты В.М. Масссонның 90 жылдық және В.С. Бочкаревтің 80 жылдық мерейтойына арналған халықаралық конференция өтті. Конференцияға 22 мемлекеттің ғалымдары қатысып, 232 баяндамалар оқылып, талқыланды. Қазақстан ғалымдарының құрамында Ә.Х. Марғұлан атындағы Археология институтының, академик Е.А. Бөкетов атындағы Қарағанды мемлекеттік университеті жанындағы Сарыарқа археологиялық институтының, А. Байтұрсынов атындағы Қостанай мемлекеттік университетінің, 
Лошакова T.H., Дубягина E.B. О работе международной конференции «Древности Восточной Европы, Центральной Азии и Южной Сибири...

С. Торайғыров атындағы Павлодар мемлекеттік университетінің, Х.Я. Яссауи атындағы Халықаралық қазақ-түрікуниверситетінің, Қорқыт ата атындағы Қызылорда мемлекеттік университетінің, ЮНЕСКО аясындағы Мәдениеттерді жақындастыру орталығының археологтары, ғылыми қызметкерлері мен ғалымдары қатысты. Қатысушылардың жұмыстары ежелгі қоғамның хронологиясы мен мәденигенезіне, ежелгі тұрғындардың мәдениетіне, энеолит-қола дәуірінің далалық мәдениеттеріне арналды.

Түйін сөздер: археология, Еуразия, Орталық Азия, Таяу Шығыс, Еуропа, Кавказ, неолит, қола дәуірі, ерте темір дәуірі, антикалық, ортағасыр, мәдениет, хронология, мәденигенез, қалалық мәдениет, мал шаруашылығы, малшылар, егін шаруашылығы, егіншілер

\section{ON THE INTERNATIONAL CONFERENCE «Antiquities of Eastern Europe, Central Asia and South Siberia in the Context of communication and interaction in the Eurasian cultural space (new data and concepts)»}

\section{T. N. Loshakova, Ye. V. Dubyagina}

On November 18-22, 2019 in St.Petersburg on the basis of the Institute of History of Material Culture of the RAS and the State Hermitage there was held an international conference "Antiquities of Eastern Europe, Central Asia and Southern Siberia in the context of communication and interaction in the Eurasian cultural space (new data and concepts)," dedicated to the 90th anniversary of the birth of V.M. Masson and 80th anniversary of the birth of V.S. Bochkarev. The conference was attended by scientists from 22 countries, 232 reports were read and discussed. Kazakhstan's scientists were represented by researchers from the A.Kh. Margulan Institute of Archeology, Saryarka Archaeological Institute at Academician E.A. Buketov Karagandy State University, A. Baitursynov Kostanay State University, S. Toraigyrov Pavlodar State University, Kh.A. Yasawi International Kazakh-Turkish University, Korkyt ata Kyzyl-Orda State University, UNESCO Centre for the Rapprochement of Cultures (Almaty). Reports of the participants were dedicated to the problems of history and cultural genesis of ancient societies, art of the ancient population of steppe culture of EneolithicBronze.

Keywords: archaeology, Eurasia, Central Asia, the Middle East, Europe, the Caucasus, Neolithic, Bronze Age, Early Iron Age, Antiquity, Middle Ages, art, chronology, cultural genesis, urban culture, cattle breeders, farmers

\section{About the Authors:}

Loshakova Tatyana N. Senior Researcher, A.Kh. Margulan Archeology Institute, Almaty, Kazakhstan; loshakovat@mail.ru

Dubyagina Yekaterina V. Researcher, A.Kh. Margulan Archeology Institute, Almaty, Kazakhstan; nkatykat@gmail.com 